\title{
Performance and Application of Alternative Water Sources in Azerbaijan
}

\author{
RAE Z H Aliyev* \\ Institute of Soil Science and Agro chemistry of ANAS Az 1073, Baku str, Azerbaijan
}

Received: 此 May 09, 2018; Published: 㘹 May 21, 2018

*Corresponding author: RAE Z H Aliyev, Institute of Soil Science and Agro chemistry of ANAS Az 1073, Baku str, M Raqima 5, Azerbaijan

\begin{abstract}
Article submitted by geographic location, geological geomorphological and soil climatic characteristics of Ganja Kazakh array coordinates and kagrizs capability in order to provide the population with fresh water.
\end{abstract}

Keywords: kjagriz; tunnel; water flow; groundwater.

\section{Introduction}

On the globe has about $2.53 \%$ freshwater, most of which have to share rivers, freshwater lakes, glaciers, groundwater. Given the scarcity of fresh water in the tropical and subtropical zones, identified the relevance of the seek alternative ways of providing the population with crops and fresh water (Figure 1). The Republic of Azerbaijan has a great variety of water resources, their education and distribution, in the territory of which the complexity of natural conditions suffers. In flat areas, the sedimentary rocks of the Mesozoic strata the present period with a lithological composition have large resources of economic, kjagrizy, drinking and artesian waters. Underground waters, it can be said, are found everywhere in modern sediments. In the foothill areas, as a result of active water exchange, these waters are slightly deeper. Their mineralization is equal to $1 \mathrm{~g} / \mathrm{l}$; the chemical composition is calcium bicarbonate. Artesian basins with high pressure on inclined parts are found in anthropogenic, Absheron, Akchag old rocks (Ganja, Gazakh, Guba-Khachmaz, Garabagh, Shirvan, etc.), and Sarmatian deposits (Nakhchivan Autonomous Republic). Their mineralization is about $1 \mathrm{~g} / \mathrm{l}$; chemical composition calcium bicarbonate, used in water supply of cities and villages, irrigation of plots. In Azerbaijan, the water balance is considered a water deficit, where the average annual flow coefficient fluctuates between 0.07-0.44. In Azerbaijan water balance is reviewed by water scarcity, where average annual runoff coefficient varies between $0.07-0.44$. In this regard, kjagrizy, as a source of depletable and renewable resources, is an indispensable, given their significant reserves and make widely available in Foothill regions of Azerbaijan, whose main function is smooth availability of input and output channels of the system alienated species and creating a backlog of ventilation and feature galleries is to ensure the release of the Earth's surface in a horizontal direction of groundwater by gravity.

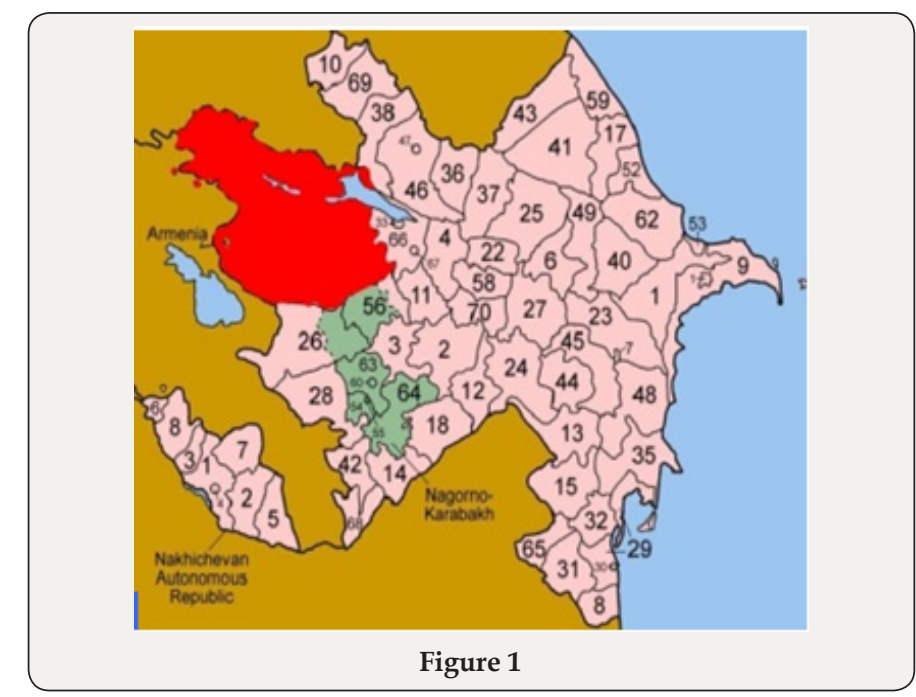

In Azerbaijan, as in many countries, even in the middle ages (2000-2200 years ago) there were many kagrizs. According to medieval sources, Azerbaijan is also one of the countries have established kjagrizy, as indicated by archaeological research: Y Hummel [1], who discovered the remains of ancient kagrizs around Shamkirchaja, belonging to 1 century b.c. The object of study is the Ganja-Kazakh sloping plain, located from the foothill zone of the north-eastern slope of the Lesser Caucasus to the right coast of r. Mtkvari, bordered on the West by r. Indzhasu and Armenia, in the South of the Murovdagskimi ridges, shahdag and on East Valley stretching Garachay include differing in their geological and 
geomorphological properties administrative districts of Gazakh, Agstafa, Tovuz, Kedabek, Shamkir, dashkasan, samukh, Goygol and Goranboy [2].

In the lowland plain with individual elevations against foothill zone is located between 400-700 m above sea level in a narrow strip and characterized by medium and highly dissected surface. This zone is located between the basis of erosion $200-400 \mathrm{~m}$, where there are favourable conditions for the formation of erosion-denudacionnogo relief. Watershed slopes dissected by gullies. North-East slope of the Lesser Caucasus presented crystalline limestone, sedimentary rocks and mergeljami, jeljuvii and delusion, which is widespread in the basin of the rivers Shamkirchay, Goshgarchaja, Ganja Kazakh and Tovuz districts, as well as Aggildzhachaja Gedabey district. On the territory of the common volcanic and sedimentary rocks of the Jurassic period of the Mesozoic and tertiary deposits and also Quaternary Cenozoic periods [3]. Shikhlinski Em [4] to the climatic zoning on the northeastern slopes of the Lesser Caucasus highlighted 3 climatic zone (subalpine, mountain-forest and suhostepovoho), which identified the following types of climate: sloping plain on the right bank of the Kura River r. Warm temperate climate semi desert and dry steppes with dry winters; the low mountains and partly Midlands (400-1500 m)-warm-temperate climate with dry winters, where annual rainfall is $50-75 \%$ evaporation.

The value of annual total radiation in the zone of low and mid is $125-130 \mathrm{kcal} / \mathrm{cm}^{2}$. Starting from an altitude of $400-500 \mathrm{~m}$ for every $100 \mathrm{~m}$, lowering the total radiation occurs $0.8 \mathrm{kcal} / \mathrm{cm}^{2}$, and radiation balance decreases by $1 \mathrm{Kcal} / \mathrm{cm}^{2}$. In dry steppe zone annual radiation balance value is $45.3-49.7 \mathrm{CAL} / \mathrm{cm}^{2}$, in the middle of the forest zone $-40.039 .0 \mathrm{kcal} / \mathrm{cm} 2$ [4]. In the Piedmont Plains average annual air temperature is $12-13^{\circ} \mathrm{c}$, gradually decreasing with the increase of gipsometricheskogo level and depending on the exhibitions and the slope of the slopes of the low and middle range from $11-13^{\circ} \mathrm{c}$.

The average January temperature in the foothill zone is-0.7$+1.5^{\circ} \mathrm{c}$ in the Midlands $(1000-2000 \mathrm{~m})-2--6^{\circ} \mathrm{c}$. The thickness of the snow cover in the foothills $(300-600 \mathrm{~m})$ is unstable and the maximum is $15-20 \mathrm{~cm}$, at an altitude of $1200-1400 \mathrm{~m}-20 \mathrm{~cm}$ and above $1500 \mathrm{~m}$ is characterized by greater thickness.

In feeding the rivers involved snow, rain, groundwater and water sources. Annual food waters sources is $45-46 \%$, snow and glacier power $35-36 \%$, rain $14-18 \%$ power throughout the year are distributed very unevenly. The greatest volume of flow $50-75 \%$ falls on spring and summer (March-June), and the lowest (10-15\%) in winter [5]. The soil cover of the Lesser Caucasus, classification and Systematics of the soils is described in detail in refs M Salayev [6], where the author points to a widespread on small Caucasus highly clayey jeljuvij maternal breeds, according the specificity of hydrothermal system. As mentioned above, studies were carried out in the districts that comprise the Ganja Kazakh sloping plain. Archival materials were used originally 1938-1940 Gg.

The Ministry of ecology and natural resources of Azerbaijan, on the basis of which the precise geographic coordinates were installed location and rated the overall situation of each kjagriza. Next on the topographic basis identified outputs kagrizs, the number of observation wells, water costs are identified and appropriate water quality tests (Figure 2) and (Tables $1 \& 2$ ). In the Tovuz district 5 kagrizs were studied, as well as in his time. They functioned in the MOP. Lower Gyryhly, Alibeyli, Gushchu, total water consumption amounted to $145 \mathrm{l} / \mathrm{s}$, the water volume used 4.57 million $\mathrm{m}^{3}$. Calculations found that the cost of water in In the Tovuz district, 5 khiriz district in the amount you can bring up to $22 \mathrm{l} / \mathrm{s}$ or 0.694 million $\mathrm{m}^{3}$, which means only in the Tovuz district with brownies used 3.374 million $\mathrm{m}^{3}$ of water that you can bring to 4.068 million $\mathrm{m}^{3}$ per year. From the foregoing it may be concluded that only in the districts of Ganja Kazakh sloping plain, there is a significant amount of fresh groundwater, using them as economically kagrizs cost of which go for a lot cheaper than the sub-artesian wells. If maintenance on laying a with brownies the system cost is 5742 USD. United States, then drilling one well sub-artesian go 22187 United States dollars [7].

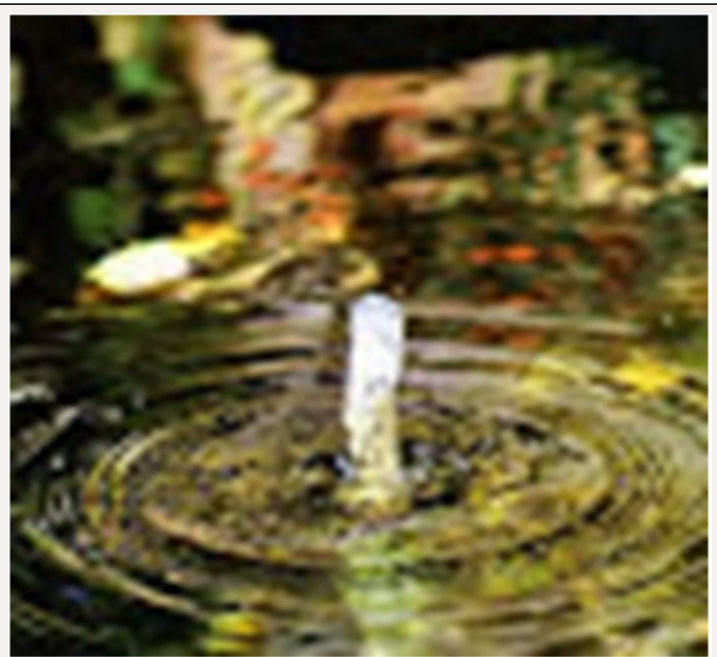

Figure 2: General view of kagrizs release and observation well. 
Table 1: Akstafa district.

\begin{tabular}{|c|c|c|c|c|c|c|c|c|}
\hline \multirow{2}{*}{ Village } & \multirow{2}{*}{$\begin{array}{c}\text { Name } \\
\text { kjagriza }\end{array}$} & \multicolumn{3}{|c|}{ Koo rdinaty (exit) } & \multirow{2}{*}{$\begin{array}{c}\begin{array}{c}\text { Length } \\
\text { kjagriza }\end{array} \\
\text { L (m) }\end{array}$} & \multicolumn{2}{|c|}{ Water Consumption $(\mathrm{l} / \mathrm{sec})$} & \multirow{2}{*}{$\begin{array}{c}\text { The } \\
\text { projected } 1 / \mathrm{s}\end{array}$} \\
\hline & & $\mathbf{X}$ & $\mathbf{Y}$ & $\mathrm{H}(\mathrm{m})$ & & 1938-g. & 2016-g. & \\
\hline \multirow[t]{2}{*}{ Gyryly } & (K) jagriz \# 1 & $\begin{array}{c}41^{\circ} 05^{`} 34.6 \\
\text { inch }\end{array}$ & $45^{\circ} 30^{\prime} 32.7^{\prime}$ & 354 & 2050 & 70 & 60 & 10 \\
\hline & (K) jagriz \#2 & $41^{\circ} 04^{\prime} 33.7^{\prime \prime}$ & $\begin{array}{c}45^{\circ} 30^{`} 0.03 \\
\text { inch }\end{array}$ & & 1450 & 35 & 30 & 3 \\
\hline $\begin{array}{l}\text { Daghkesemen } \\
\text { village }\end{array}$ & $\begin{array}{l}\text { Daghkesemen } \\
\text { village }\end{array}$ & $41^{\circ} 04^{\prime} 36.2^{\prime}$ & $45^{\circ} 29^{\prime} 27.6^{\prime \prime}$ & 384 & 1420 & - & - & - \\
\hline Jejnally & Jejnally 1 & $41^{\circ} 04^{\prime} 33.7^{\prime \prime}$ & $\begin{array}{c}45^{\circ} 30^{`} 0.03 \\
\text { inch }\end{array}$ & 376 & 20 & - & - & - \\
\hline Jejnally & Jejnally 2 & $41^{\circ} 03^{\prime} 57.6^{\prime \prime}$ & $45^{\circ} 29^{\prime} 59.2^{\prime}$ & 394 & 1000 & 40 & 30 & 6 \\
\hline $\begin{array}{c}\text { Upper } \\
\text { Gojchali }\end{array}$ & Gojchali & $41^{\circ} 02^{\prime} 33.7^{\prime \prime}$ & $45^{\circ} 28^{\prime} 53.6^{\prime}$ & 430 & 1100 & 25 & 20 & 3 \\
\hline Pic Vurgun. & Vurgun & $41^{\circ} 05^{\prime} 12.7^{\prime}$ & $45^{\circ} 28^{\prime} 37.1^{\prime \prime}$ & 385 & 1900 & - & - & - \\
\hline (K) ochasker & $(\mathrm{K})$ ochasker & $41^{\circ} 02^{\prime} 54.8^{\prime}$ & $45^{\circ} 79^{\prime} 38.7^{\prime \prime}$ & 435 & 2100 & 25 & 20 & 4 \\
\hline \multicolumn{6}{|c|}{ SUBTOTAL: } & 195 & 160 & 26 \\
\hline \multicolumn{9}{|c|}{ Kazakh district } \\
\hline Chajly & Chajly & $41^{\circ} 05^{\prime} 58.3^{\prime}$ & $45^{\circ} 16^{\prime} 39.5^{\prime \prime}$ & 451 & 1750 & 42 & 50 & - \\
\hline \multicolumn{6}{|c|}{ SUBTOTAL: } & 42 & 50 & - \\
\hline \multicolumn{9}{|c|}{ Tovuz district } \\
\hline Gore. Tovuz & Vidzavod & $40^{\circ} 59^{\prime} 37.2^{\prime \prime}$ & $45^{\circ} 37^{\prime} 17.6^{\prime}$ & 423 & - & - & - & - \\
\hline \multirow[t]{6}{*}{$\begin{array}{l}\text { Lower } \\
\text { Gushchu }\end{array}$} & $\begin{array}{l}\text { Lower } \\
\text { Gushchu }\end{array}$ & $40^{\circ} 56^{\prime} 0.08^{\prime}$ & $45^{\circ} 39^{\prime} 57.6^{\prime \prime}$ & 514 & 500 & 35 & 26 & 5 \\
\hline & Gurdlar & $40^{\circ} 56^{\prime} 0.02^{\prime}$ & $45^{\circ} 40^{\prime} 9.3^{\prime}$ & 519 & 240 & - & - & - \\
\hline & $\begin{array}{l}\text { Mohammed } \\
\text { Aga }\end{array}$ & $40^{\circ} 56^{\prime} 16.8^{\prime \prime}$ & $45^{\circ} 39^{\prime} 54.1^{\prime}$ & 503 & 550 & 30 & 26 & 4 \\
\hline & Duz Gyrygly & $40^{\circ} 59^{\prime} 8.5^{\prime}$ & $45^{\circ} 48^{\prime} 21.0^{\prime \prime}$ & 293 & 800 & 60 & 40 & 10 \\
\hline & Gum-Mjulkulu & $40^{\circ} 56^{\prime} 40.9^{\prime \prime}$ & $45^{\circ} 30^{\prime} 32.2^{\prime}$ & 585 & - & - & - & - \\
\hline & $\begin{array}{l}\text { Gum-Top } \\
\text { Mjulkulu }\end{array}$ & $40^{\circ} 56^{\prime} 37.2^{\prime \prime}$ & $45^{\circ} 30^{\prime} 26.2^{\prime}$ & 597 & 620 & - & 15 & 3 \\
\hline SUBTOTAL: & & & & & & 125 & 107 & 22 \\
\hline
\end{tabular}

Table 2: Shamkir district.

\begin{tabular}{|c|c|c|c|c|c|c|c|c|}
\hline 1 & 2 & 3 & 4 & 5 & 6 & 7 & 8 & 9 \\
\hline & $\begin{array}{c}\text { Zejam } \\
\text { Dzhyrdahan }\end{array}$ & $40^{\circ} 52^{\prime} 3.9 \mathrm{inch}$ & $\begin{array}{c}45^{\circ} 49^{\prime} \\
52.8^{\prime}\end{array}$ & 539 & 500 & 24 & 1.5 & 15 \\
\hline \multirow[t]{2}{*}{$\begin{array}{c}\text { Irmashly (cwas eating } \\
\text { was Jengls) }\end{array}$} & Garaoglanly & $40^{\circ} 50^{\prime} 14.7^{\prime}$ & $\begin{array}{l}45^{\circ} 51^{\prime} \\
44.6^{\prime \prime}\end{array}$ & 597 & 465 & 20 & 6 & 12 \\
\hline & Chief kjagriz & $40^{\circ} 49^{\prime} 16.4^{\prime \prime}$ & $\begin{array}{l}45^{\circ} 52^{\prime} \\
43.7^{\prime}\end{array}$ & 619 & 600 & 30 & 20 & 10 \\
\hline \multirow[t]{2}{*}{ Shishtepe Village } & Small Kjagriz & $40^{\circ} 50^{\prime} 34.8^{\prime \prime}$ & $\begin{array}{l}45^{\circ} 55^{\prime} \\
31.1^{\prime \prime}\end{array}$ & 493 & 600 & 10 & 4 & 6 \\
\hline & Big kjagriz & $40^{\circ} 49^{\prime} 31.7^{\prime}$ & $\begin{array}{l}45^{\circ} 55^{\prime} \\
44.9^{\prime}\end{array}$ & 550 & 450 & 25 & 20 & 7 \\
\hline c. Morulu & Gasanaga & $40^{\circ} 48^{\prime} 26.9 .^{\prime}$ & $\begin{array}{l}46^{\circ} 0000^{\prime} \\
32.3 \text { inch }\end{array}$ & 533 & 980 & 20 & 74 & 15 \\
\hline c.. Morulu & Kjagriz & $40^{\circ} 46^{\prime} 52.8^{\prime}$ & $\begin{array}{l}46^{\circ} 0000^{\prime} \\
19.3 \text { inch }\end{array}$ & 626 & 850 & 30 & 20 & 8 \\
\hline Morulu-Sarhanly & Sarhanly & $40^{\circ} 46^{\prime} 41.8^{\prime \prime}$ & $\begin{array}{l}46^{\circ} 0000^{\prime} \\
23.2^{\prime \prime}\end{array}$ & 639 & 450 & 25 & 20 & 5 \\
\hline \multicolumn{6}{|c|}{ SUBTOTAL: } & 184 & 165.5 & 78 \\
\hline
\end{tabular}




\begin{tabular}{|c|c|c|c|c|c|c|c|c|}
\hline \multicolumn{9}{|c|}{ Geranboy district } \\
\hline & Ashyrly & $40^{\circ} 32^{\prime} 58.4^{\prime}$ & $\begin{array}{c}46^{\circ} 47^{\prime} \\
45.6^{\prime}\end{array}$ & 216 & - & - & - & - \\
\hline & Meschid & $40^{\circ} 32^{\prime} 14.7^{\prime}$ & $\begin{array}{c}46^{\circ} 46^{\prime} \\
51.7^{\prime}\end{array}$ & 268 & 250 & 15 & 7 & 7 \\
\hline \multirow[t]{2}{*}{ Tatarli } & Lezgi & $40^{\circ} 31^{\prime} 25.8^{\prime}$ & $\begin{array}{c}46^{\circ} 46^{\prime} \\
21.3^{\prime \prime}\end{array}$ & 298 & 1500 & 28 & 20 & 8 \\
\hline & Ragimbejli & $40^{\circ} 32^{\prime} 38.0^{\prime}$ & $\begin{array}{c}46^{\circ} 46^{\prime} \\
27.9^{\prime \prime}\end{array}$ & 264 & 1200 & 22 & 13 & - \\
\hline Dashalty Qaraqoyunlu & $\begin{array}{c}\text { Dashalty } \\
\text { Qaraqoyunlu }\end{array}$ & $40^{\circ} 29^{\prime} 3.8^{\prime \prime}$ & $\begin{array}{c}46^{\circ} 46^{\prime} \\
33.0^{\prime}\end{array}$ & 348 & 700 & 40 & 15 & 15 \\
\hline \multirow[t]{3}{*}{ c. Kocharli } & $\begin{array}{c}\text { To the } \\
\text { East from } \\
\text { ahmedagali }\end{array}$ & $40^{\circ} 17^{\prime} 41.9^{\prime}$ & $\begin{array}{l}47^{\circ} 03^{\prime} \\
39.1^{\prime \prime}\end{array}$ & 107 & 450 & 24 & 18 & 4 \\
\hline & $\begin{array}{c}\text { c. the } \\
\text { East from } \\
\text { Ahmedagali }\end{array}$ & $40^{\circ} 18^{\prime} 42.8^{\prime}$ & $\begin{array}{c}47^{\circ} 03^{\prime} \\
42.1^{\prime}\end{array}$ & & - & - & - & - \\
\hline & Mamyrly & $40^{\circ} 18^{\prime} 49.2^{\prime}$ & $\begin{array}{l}47^{\circ} 04^{\prime} \\
17.5^{\prime \prime}\end{array}$ & 108 & - & - & - & - \\
\hline \multirow[t]{2}{*}{ Garadagly Village } & Kjagriz & $40^{\circ} 40^{\prime} 4.5^{\prime}$ & $\begin{array}{c}46^{\circ} 33^{\prime} \\
42.8^{\prime}\end{array}$ & 296 & - & - & - & - \\
\hline & Caravanserai & $40^{\circ} 40^{\prime} 23.9^{\prime}$ & $\begin{array}{l}46^{\circ} 34^{\prime} 1.8 \\
\text { inch }\end{array}$ & 1215 & - & - & - & - \\
\hline \multicolumn{6}{|c|}{ SUBTOTAL: } & 129 & 53 & 34 \\
\hline \multicolumn{9}{|c|}{ Geygel district } \\
\hline & Haji Asker & $40^{\circ} 40^{\prime} 39^{\prime}$ & $\begin{array}{c}46^{\circ} 12^{\prime} \\
45.6^{\prime}\end{array}$ & 665 & 900 & 20 & 0.5 & 15 \\
\hline & Balchylar & $40^{\circ} 07^{\prime} 49.6^{\prime}$ & $\begin{array}{c}46^{\circ} 16^{\prime} \\
35.8^{\prime}\end{array}$ & 450 & & 55 & 42 & 10 \\
\hline & $\begin{array}{l}\text { 2-nd kjagriz, } \\
\text { 2-nd sleeve }\end{array}$ & $40^{\circ} 36^{\prime} 18.5^{\prime \prime}$ & $\begin{array}{c}46^{\circ} 21^{\prime} \\
51.2^{\prime}\end{array}$ & 592 & & - & - & - \\
\hline \multirow[t]{4}{*}{ c. Balchyly } & Kjagriz & $40^{\circ} 40^{\prime} 49.6^{\prime}$ & $\begin{array}{c}46^{\circ} 16^{\prime} \\
35.8^{\prime}\end{array}$ & 450 & 840 & 54 & 42 & 10 \\
\hline & $\begin{array}{l}\text { German } \\
\text { kjagriz } 1\end{array}$ & $40^{\circ} 35^{\prime} 52.8^{\prime}$ & $\begin{array}{c}46^{\circ} 19^{\prime} \\
47.8^{\prime}\end{array}$ & 650 & & 12 & 8 & 4 \\
\hline & $\begin{array}{r}\text { German } \\
\text { kjagriz } 2\end{array}$ & $40^{\circ} 36^{\prime} 18.5^{\prime \prime}$ & $\begin{array}{c}46^{\circ} 21^{\prime} \\
51.2^{\prime}\end{array}$ & 592 & & 20 & - & 15 \\
\hline & $\begin{array}{c}\text { Private } \\
\text { kolodec } \\
\text { Kjagriznyj }\end{array}$ & $40^{\circ} 33^{\prime} 49.1^{\prime}$ & $\begin{array}{c}46^{\circ} 21^{\prime} \\
09.3^{\prime}\end{array}$ & 605 & & - & - & - \\
\hline SUBTOTAL: & & & & & & 151 & 92.5 & 54 \\
\hline
\end{tabular}

\section{Conclusion}

An analysis of the conducted researches should conclude that at the present stage of development of the economy, expansion of irrigation hectares of crops to ensure food for the increasing number of population, as well as shortage of fresh water in arid zones of Azerbaijan and economic efficiency, the laying of new and reconstruction of destroyed kagrizs, it is necessary to pay special attention, as one of the alternative sources of fresh water.

\section{References}

1. Gummel Ek (1939) Report on the excavation of some Kirovabad in 1938. г, izv Azerbaijan National Academy of Sciences, Baku 3: 66.
2. Antonov Bi (1959) Lesser Caucasus In: geology of Azerbaijan (Geomorphology). Ed an Azeri SSR, Baku pp. 192-250.

3. Sh Azizbeyov (1947) Geology and petrography of the north eastern part of the Lesser Caucasus. Ed an Azeri SSR.

4. (1968) Em shikhlinski climate in Azerbaijan, Baku, with 341.

5. (2002) Mamedov Hydrography of Azerbaijan, Baku, 266 pp (in Azeri).

6. Salayev ME (1966) Soil Small Ka in Casa. Ed Academy of science of the Azerbaijan SSR, Baku, 326p.

7. Kuliev ag (2010) kagrizs System, j NDU ar 159 (in Azeri). 
(C) This work is licensed under Creative

To Submit Your Article Click Here: Submit Article

DOI: 10.32474/MAOPS.2018.01.000121

Assets of Publishing with us
- Global archiving of articles
- Immediate, unrestricted online access
- Rigorous Peer Review Process

